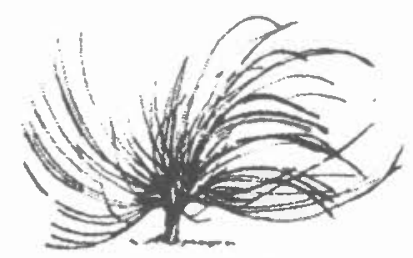

\title{
Classroom interaction and language learning among boys in coed and single-sex contexts
}

\author{
Roberto Enrique Rojas Alfarol \\ Universidad Nacional, Costa Rica \\ Heredia, Costa Rica \\ rera15@gmail.com
}

\begin{abstract}
Resumen
Esta ponencia abordará las diferencias y las similitudes en los patrones de aprendizaje del inglés como idioma extranjero en varones según su entorno de aprendizaje específico. A través de la presentación, se mostrarán los resultados de una investigación cualitativa llevada a cabo en el aula diferenciada y mixta en dos colegios en Costa Rica, a saber, Colegio Yorkin y Colegio Nueva Esperanza respectivamente. La recolección de datos incluye la observación de las clases, las entrevistas personales, las encuestas y cuestionarios a varones y profesores respecto a estilos y preferencias de aprendizaje, las fotografias etnográficas y los artefactos. Los resultados demostraron que los varones entre varones en ambos contextos aprenden y se comportan de forma similar independientemente del entorno de aprendizaje específico en el cual se encuentran inmersos. Se evidenció la preferencia por estilos de aprendizaje del tipo kinestésico, cognitivo y orientado en tareas. Además de sugerir la necesidad de cambios en el sistema educativo, el estudio pone de manifiesto algunas
\end{abstract}

Recibido: 21 de febrero, 2011 - Aprobado: 29 de junio, 2011

1 Máster y Profesor de inglés de la Universidad de Costa Rica en la sede de Guanacaste. 
implicaciones para los profesores de forma que adapten sus estrategias de enseñanza para favorecer los estilos de aprendizaje de los varones.

Palabras claves: Varones, idioma extranjero, género, estilos de aprendizaje, colegio, profesores de idiomas, estrategias de enseñanza, educación diferenciada, educación mixta.

\begin{abstract}
This lecture will address the differences and similarities in EFL interactive patterns of boys' learning in gender specific learning environments. The presentation will explore the findings of observational research conducted in coeducational and single-sex classrooms in two secondary schools in Costa Rica, namely Yorkin and New Hope Schools. Data collection included class observation, interviews, surveys, questionnaires, photo ethnography and artifacts. The results revealed that boys in both contexts actually learn and behave similarly regardless of the gender specific learning environment in which they were immersed. They evidenced preference for kinesthetic, cognitive learning styles and task-oriented learning. Besides suggesting the need for school changes, the study brings out implications for teachers to adapt teaching strategies to accommodate their boys' learning styles.
\end{abstract}

Keywords: boys, EFL, gender, learning styles, school, language teachers, teaching strategies, single-sex education, coeducation.

$\mathbf{P}$ revious approaches to teaching languages have evolved overtime in order to improve the effectiveness of teaching practices and the meaningfulness of individuals' learning. In Costa Rica, it is not a novelty to hear about new approaches and/or teaching strategies for communicative purposes in the language classroom. However, teaching strategies which focus on gender-specific learning styles have not been given much attention; in particular learning about specific approaches in helping boys learn separately. 
School teachers, as facilitators of knowledge and learning experiences, are responsible for teaching boys and helping them learn. Their role is fundamental since they encourage and challenge students to finally succeed in life. Accordingly, language teachers cannot go about fostering communicative competence without taking into account boys' learning differences that depending on the context in which they coexist, may enhance or even inhibit their communication learning skills. Hence, schools play a significant role as institutions in charge of enlightening and forming individuals as well as providing a suitable environment for them to acquire knowledge and grow as people. Therefore, schools and teachers should take a closer look at their boys' needs; they should pay attention to other aspects related to their learning: their learning uniqueness and their need of a meaningful learning experience based on individual gender learning styles.

This observational study presents several differences and similarities in EFL interactive patterns of boys' learning in gender specific learning environments. More specifically, this study aims at shedding some light on the differences and similarities between coed and singlesex education in regard to interactive patterns of Gender Specific English as Foreign Language (GSEFL) learning among boys at Yorkin and New Hope Schools, both private/middle to upper class institutions located in San José and Heredia, Costa Rica respectively. The populations observed were two groups of ninth grade students, 19 boys at Yorkin and 11 boys at New Hope, ranging in ages from 15 to 16 , who enrolled in their respective schools during the second half of the school year 2009. Four language teachers, two per school, were also observed and interviewed for the study.

Data collection included class observation, interviews, surveys and questionnaires on cognitive/learning styles and learning preferences, photo ethnography and artifacts. The results revealed that boys among boys in both contexts actually learn and behave similarly regardless of the gender specific learning environment in which they were immersed. There was preference for kinesthetic, cognitive learning styles and task-oriented learning. As a result of the data, the study brings out implications for teachers to adapt teaching strategies to accommodate their boys' learning styles. 


\section{Theoretical framework}

Gender differences and education have been the subject of interest in the last decades around the world (Gurian and Stevens, 2005; Sax, 2005). In fact, research results have evidenced that old theories about boys' learning are inaccurate in determining how they learn (Gurian and Stevens, 2005). Hence, new theories have come to enlighten current practices in teaching boys separately. According to Gurian, Stevens and Daniels (2009), boys and girls should be given special attention during their learning process, not only because of the acquisition of knowledge or how effective methods have proven to work, but also because of their "gender learning uniqueness" as they state that "boys (and girls) don't process information the same way, and can benefit from strategies that match their learning styles" (p. 23). Hence, understanding how boys learn - and more important how to teach them - is likely to become a real challenge for many language teachers if they lack the experience and knowledge in the field of gender education.

Richards and Lockhart (1999) assert that "teaching is a complex process which can be conceptualized in a number of different ways [involving] (...) a cognitive, an effective, and a behavioral dimension" (p. 29). Also, Gärderfors (2007) adds that "a focal theme for education science should be to identify those pedagogical practices that foster in-depth student understanding" (p. 68). That is, teachers who have a deeper understanding of their own knowledge will be able to generalize their own knowledge and transmit it to others (p. 69). In this regard, Fleming (2006) suggests that in order to encourage a gender perspective in Costa Rica's public education system, it is necessary to implement a two-way process: a process of understanding toward gender equity, and another of self-learning in that field (p. 20). The ideas of the authors behind this theoretical framework might be exemplified by the experiences of some language teachers in Costa Rica who may be accustomed to a coed model in which they teach each individual in the same manner, not truly considering the possibility of employing gender-specific strategies to teach boys separately, based on their own learning styles and cognitive preferences.

Gurian et al (2009) claim that "though many boys (and girls) can take their brain differences into coed classrooms and succeed quite well, some do not" (p. 23). This is why teachers should reflect on their 
current practices in the language classroom. Boys' learning styles ought to be valued and highlighted as individual abilities - not teaching constraints, and teachers should adopt strategies to fit each gender learning preference. In other words, a better understanding of boys' learning styles might suppose that the more teachers know about boys' learning styles, the more suitable it is to approach them in learning a foreign language. Additionally, schools' contexts, including classroom settings, play important roles in successfully teaching boys.

According to Norfleet James (2007), "many boys do not see school success as a masculine trait;" they may well see in learning a foreign language something difficult to assimilate and perhaps useless in their daily lives. This author explains that boys' belief is that "school is for girls, and many girls would agree." Also, some boys might not have trouble in school, but others are not succeeding as expected. As a result, boys are failing their courses, dropping out, or even worse not going beyond high school (p. 6). Neu and Weinfeld (2007) agree with Norfleet James' statement as they also assert that "besides trailing in academic performance, boys are more likely to drop out of high school than girls and less likely than their female counterparts to graduate high school, to attend college, and to go on for graduate degrees" (Mortenson, 2005 in citing Neu and Weinfeld, 2007, p. 3).

These alarming results are the ones described by Gurian et al (2009) among other authors who are concerned by this problem (p. 22). These authors emphasize that, in spite of boys' potential to learn in nearly any environment, "the vast majority of children, who are not succeeding, in class after class, are boys." Besides, they affirm that "it is not boys who are the problem but schools" (p. 23). Conscious of this reality, Gurian and Stevens (2005) add that teachers should discern that boys "are not blank slates or determined by genetics alone, but creatures of three formative powers: nature, nurture, and culture" (p. 43).

At this point, many teachers may actually wonder or even question whether boys' mismatch in the current Costa Rican school system is the fault of the school system itself, i.e. Costa Rica's public school system; these teachers might not be sure as to what is suitable or appropriate in helping boys succeed, overcome inner difficulties and/ or achieve the goals proposed as standards in their school syllabus. In fact, it is worrisome and difficult to digest the idea that the Costa Rican society has changed a great deal, threatening boy students to a point in 
which they must fit into a "unisex" model. Then "the image of a schoolchild as someone sitting and reading has become the poster image for education, especially in the last fifty years" (Gurian et al, 2005, p. 53). In Neu and Weinfeld's (2007) words, "rather than changing the boys to fit our schools, schools [and teachers] might change to capitalize and expand on the strengths of boys" (p. 2). This change may well signify a shift in boys' learning.

As a matter of fact, teachers should reflect on what is not working in their classrooms to make their teaching more effective and consequently their boy students' learning meaningful. In Norfleet James' (2007) words, teachers should reconsider their teaching theories to understand that "boys who are not succeeding in an educational setting are not necessarily unable to learn, but instead learn in very different ways from those for which classrooms are now structured" (p. 5). Similarly, Neu and Weinfeld (2007) suggest that "the first step toward making changes in how we educate boys is to have a common understanding of the problems that boys currently face and an understanding of the possible causes of those problems" (p. 2). Hence, education plays a chief role in renovating social practices as Bonder (1998) affirms, "teaching empowers the creation of new cultural perspectives" (p. 19). That is, teaching shapes and "nurtures" boys as they grow up and coexist among other individuals and themselves, empowering them to become better people.

\section{Similarities and differences regarding boys' interaction in the language classroom}

Interaction in education can be understood as the participation of individuals in the language classroom carrying out learning tasks (Richards and Lockhart, 1996, p. 141). This involvement and contribution can be observed in groups of boys while their teachers, facilitators of knowledge, promote interaction through learning tasks. Consequently, the effectiveness of those learning tasks can be observed through boys' patterns of interaction in the classroom which is clear from their perceptions and feelings toward EFL learning activities proposed by their teachers. Classroom interaction, an ability described by Richards and Lockhart (1996) as "the rules that students are expected to follow in order to participate appropriately in lessons" (p. 144) was observed as an important component of foreign language learning. On the other 
hand, teachers are also responsible in providing learning activities that accommodate their boys' learning and cognitive styles.

The following ideas were generated through the observation of boys' behavior in the language classroom as well as their perceptions and feelings gathered from personal interviews, and teachers' comments made on a survey. Again, it is important to remark that these ideas emerged from the interactional patterns that boys showed in the language classroom in two different settings: both coed and single-sex contexts. Such ideas are organized as similarities and differences among boys interacting in the language classroom.

Similarities that emerged from observation in the language classroom in both contexts concerning boys' involvement and contribution revealed that boys are very active learners in tasks involving physical movement. According to Gurian et al (2009), "boys must engage their hands and bodies in order to engage their minds" (p. 90). These authors explain that teachers will primarily discover that "the way boys use space and how they like to move around when doing their tasks" is natural. In contrast, when boys find themselves apart from class activities, they do anything else that entertains them -boys' reactions toward sitting down quietly and still are evidently uncomfortable for themselves and their teachers who see them moving around, talking among themselves, listening to music, etc.

Another aspect observed is that boys usually direct their attention to objects in the classroom or ideas in their heads when they are "absent-minded," which prevent them from participating in learning tasks taking place in the classroom, so that they are lost when called on to participate. Gurian et al (2009) explain that boys' minds go into a "rest state" especially when the teacher has been talking for more than ten or fifteen minutes. Consequently, boys are not likely to succeed. These authors agree that boys' unconscious actions as tapping a pencil or beginning to fidget, among others, "are signals that [their] attention is wandering and [they are] in need of physical movement to reenergize their minds for learning" (p. 95). Thus, certain strategies should be employed to help them get on track again since boys are often easily distracted when there is nothing to do. According to Mr. Hicks, boys' attention span is too short so that it is necessary to give them "mini breaks" to get on track again (personal communication, September 28, 2009). 
It was also noticed through observation that boys get engaged in class activities when their teachers talk to them about things not necessarily related to the topic under discussion or call for their participation often. Also, boys approach their teachers to ask questions anywhere their teachers are. In fact, boys show more confidence and commit themselves to a class when their teachers show they are accessible and friendly i.e. not too strict, not too laid-back. Besides, boys respond better to learning tasks when teachers are constantly monitoring their work, and helping and encouraging them in accomplishing those tasks in a competitive way. In fact, boys find competition attractive as they make fun of their classmates who make mistakes or get punished for not paying attention to the task at hand. It is equally evident that it is easier to get boys involved when their teachers entertain them. Gurian et al (2009) explain that "a sense of humor is important to develop and encourage in boys, as it helps them to build friendship and better deals with their world." Besides, they affirm that humor works as a great means for boys to bond and form teams (p. 91).

Some differences were also observed in the two classroom settings. Boys' behavior regarding participation and involvement in classroom tasks at New Hope School showed a certain disparity compared to the behavior that boys at Yorkin School demonstrated due to their interaction with female classmates. Thus, boys in the coed setting demonstrated lack of interest when their instructors adopted a teacher-centered approach, lecturing their class. Consequently, boys tend to yawn, lean their arms and heads on their desks, look through the window or talk to other boys around them while most girls are paying attention to their teachers. Gurian et al (2009) affirm that "female students sit quietly, listen to directions and stay in their seats, whereas the male students like to talk more and move around the room." Also, boys avoid whole-class interaction and complain about the length of certain tasks that take a long time to accomplish. During interview sessions, a boy declared to have experienced peer pressure and embarrassment in the classroom because of girls' better performance, participation and accuracy in language development tasks. Besides, it was demonstrated through observation that girls usually volunteer because nobody else does. Actually, most students who volunteer are girls - boys must repeatedly be asked to participate. Also, girls are more active than boys in the classroom when asked to answer questions and/or make comments on topics their teachers have already addressed. 
These differences in interaction are noticeable in a classroom where girls have the control of the class interaction in regard to participation and accomplishment of learning tasks. As Richards and Lockhart (1996) describe it, "because of individual differences in learners" personalities and their individual cognitive styles, different patterns of interaction can often be observed among learners in any one class" ( $p$. 114). This statement, along with this study's findings, demonstrate that in order to promote a friendly environment for boys to interact in the language classroom, it is necessary for teachers to accommodate learning tasks to what boys are likely to enjoy most, establishing a balance among each individual's interests and likes. Other differences in boys' interactional patterns were noted at Yorkin School as it was observed that boys laugh and get more enjoyment when their teacher "makes a clown out of himself" and/or uses funny expressions and/or gestures to explain something. Besides, boys demonstrated liking controversy as they find some interest in discovering new or unknown things. In other words, when they do not know what is going on, they look forward to getting involved in learning it.

\section{Boys' patterns of interaction in the language classroom}

A boy described his interests and those of some of his classmates -and consequently their interaction in the classroom-at Yorkin School.

Two more students are with me, asking questions about my work. I ask one student next to me why he is not with the teacher, paying attention to what he is teaching the others. He replies that he is talking to me in English anyway. Therefore, I ask him if he would join those seven students with the teacher if I was not here to which he answers "yes." After that, I question him on the behavior of his classmates at the back of the room. He says they are there because they may not be interested in the lesson. (Personal communication, August 28, 2009)

The previous paragraph clearly portrays boys' intentions in the language classroom. If they are interested in the topic being addressed or the activity in progress, they will accompany their teacher and their other boy classmates - this is a matter of choice. Gurian et al 
(2008) affirm that "much of the adolescent brain's successful future in the world will depend not only on how it learns positive choice-making but also on how the adults around the adolescent help his brain do that learning" (p. 69). Hence, teachers should lay emphasis on how they teach their boys as they are responsible for creating awareness among their boy students on what they have to do or are meant to do. Accordingly, the nature of boys' interactional patterns may also be understood by analyzing their learning and cognitive styles.

Figure 1. Perceptual learning style preferences

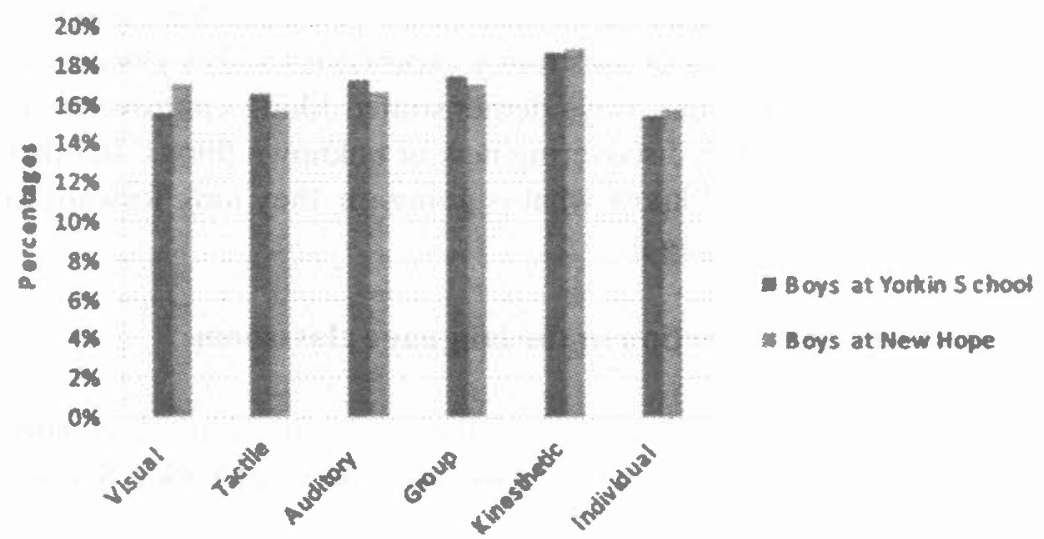

Leamine styles

The analysis of the first questionnaire demonstrated that boys in both settings exhibited a stronger preference for a kinesthetic learning style. In this sense, they demonstrated favoring activities in which they learn by doing something in class, by performing in role-playing or similar activities including physical movement. Their second major choice in both contexts was interpersonal (group) learning style. Thus, boys go for activities in which they have to work cooperatively in pairs or groups, usually looking forward to getting involved in related activities. Finally, boys' third choice as their favorite learning style differed from one school to the other. Yorkin School boys showed preference for an auditory learning style. Learners with this preference are better 
listeners. They like the teacher to give instructions orally. They also remember things when they hear them in class better than things they read. Additionally, they learn better when they listen to someone. On the other hand, boys at New Hope School demonstrated favoring a visual learning style. Students with this preference like reading what the teacher writes on the board. They also like reading instructions as they remember them better. Additionally, they learn more successfully by reading textbooks than by listening to someone. Other learning styles such as tactile and individual modes showed a certain level of acceptance among boys in both contexts but less impact than their learning preference. Although boys' learning style choices varied in minimum proportions gradually, their three main learning styles evidenced students' preference for the type of learning activities that make them interact more in the language classroom.

As well as boys' learning styles, cognitive styles were analyzed to learn more about learners' interactive patterns in the language classroom in both coed and single-sex contexts. According to Richards and Lockhart (1996), "cognitive styles can be thought of as predispositions to particular ways of approaching learning and are intimately related to personality types" (p. 59). Thus, boys' cognitive styles were identified to understand their interactional patterns in the language classroom based on their own perceptions and feelings in relation to their learning preferences.

Figure 2. Cognitive styles

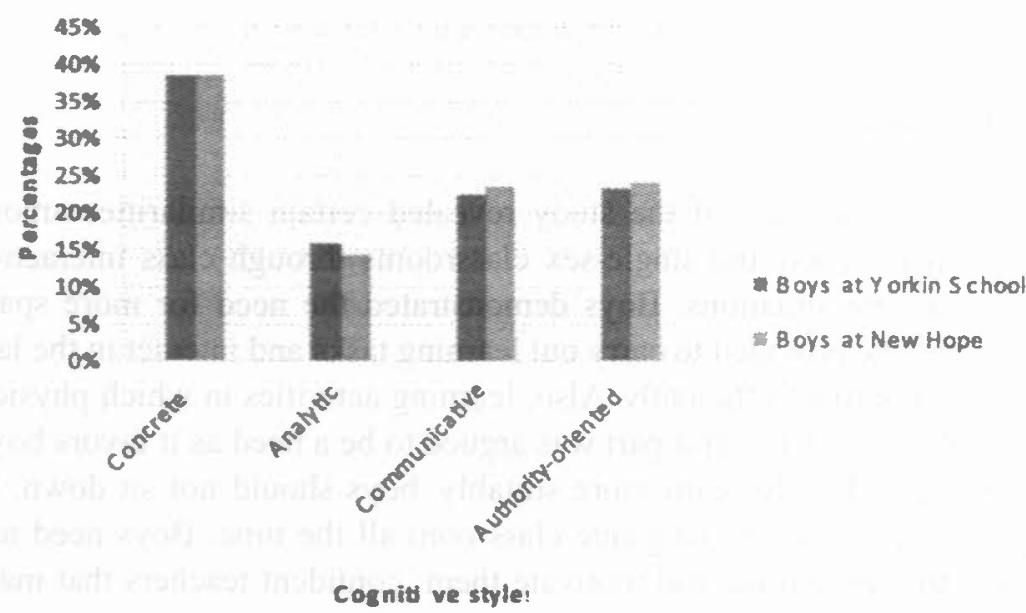


Both groups of boys demonstrated very similar cognitive styles, favoring a concrete style;

hands-on activities, a dislike for routine classroom tasks and generally a style which consists of active and direct learning. Thus allowing boys to handle and process the information that has immediate value for them, with a constant change of pace. Also, it favors boys who are spontaneous and curious; willing to take risks. In a less significant proportion, they demonstrated communicative, authority-oriented and analytic styles. The two second favorite cognitive styles in both settings, communicative and authority-oriented types, are related to: 1) a social process of discovering new things and learning through group activities in which communication is essential, and 2) a means to get information and direction by a tutor; that is, constant supervision and assistance in learning tasks, correcting of mistakes and approval of successfully accomplished learning tasks.

Finally, an analytic style was also demonstrated to take part in boys' learning in both contexts but in a minimal degree. This means that some boys also like working in some tasks apart, intending to analyze something by themselves and approaching activities in a more serious way, committing themselves to accomplish those tasks with success (Richards and Lockhart, 1996, p. 60). Cognitive styles such as the ones demonstrated by boys from both schools and the degree of impact in their learning preference confirmed that boys are actually very active and competitive learners, who provided with meaningful and challenging activities, will successfully accomplish learning tasks and participate more enthusiastically in the language classroom.

\section{Conclusions}

The outcome of the study revealed certain similarities among boys in the coed and single-sex classrooms through class interaction and learning situations. Boys demonstrated the need for more space than the one provided to carry out learning tasks and interact in the language classroom efficiently. Also, learming activities in which physical movement is an integral part was argued to be a need as it favors boys' learning styles. To learn more suitably, boys should not sit down, be quiet and still in the language classroom all the time. Boys need teachers that encourage and motivate them; confident teachers that make 
boys automatically engage in classroom activities and participate more effectively. They must find meaning in the learning tasks proposed by their EFL teachers i.e. educators who bring controversy to the classrooms encourage boys more to get engaged in learning tasks. It was observed that boys need to be engaged with attractive tasks; teacher who employ elements of surprise in the classroom make their classes unpredictable. Thereby, accommodating the activities which suit boys' learning and cognitive styles. Thus, if differences in these two areas are identified and considered when teaching, boys will significantly vary their interactional patterns. Hence, students' boredom is converted into a willingness to become active learners in a classroom that suits their nature; their "uniqueness [as learners]" of a foreign language (Gurian, Stevens and Daniels, 2005, p. 23). Few differences emerged from the data analysis as many boys in the coed setting adopted a passive learner role in the language classroom given the fact that girls, empowered by the school context and their teachers favoring their learning styles, were provided better conditions in which to interact and actively participate.

Cognitive styles as the ones demonstrated by boys from both schools and the degree of impact in their learning preference confirmed that boys are actually very active and competitive learners that provided with meaningful and challenging activities will accomplish successfully with learning tasks and participate more enthusiastically in the language classroom. The boys in both contexts demonstrated to be task-oriented students, favoring both the kinesthetic learning style and concrete style. That is evidence of their favorite interactive pattern in the language classroom; just as the previous findings on boys' interaction in the classroom portray what Richards and Lockhart (1996) state, "(..) while it is not necessary to put learners into boxes labeled according to cognitive styles, it is useful to try to identify which approaches to learning they favor and how teaching can accommodate their learning preferences" (p. 62). Thus, from these patterns of interaction demonstrated through boys' participation in learning tasks in these two contexts, teachers should identify and accommodate their lesson planning activities to suit boys' learning styles. The more teachers know about boys' learning styles, the more effective their strategies will be in teaching a foreign language. 


\section{REFERENCES}

\section{Books and web sources}

Bonder, Gloria. (1998). Construcción de la Igualdad de Oportunidades Educativas, Según el Género, en Escuelas Lideres. Costa Rica: Ministerio de Educación Pública.

Fleming, Ivette. (2006). Informe Sobre Equidad de Género en el Ámbito Educativo en Costa Rica. Retrieved from http://mail.google.com/mail/?shva=1\#search/ ivette+fleming

Gärderfors, Peter. (2007). Understanding Cultural Patterns. In Suarez-Orozco, Marce10 M. (2007). Learning in the Global Era. California: University of California Press.

Gurian, Michael and \& Stevens, Peggy. (2005). The Minds of Boys. San Francisco: Jossey-Bass.

Gurian, Michael, Kathy Stevens \& King, Kelly. (2008). Strategies for Teaching Boys and Girls. San Francisco: Jossey-Bass.

Gurian, Michael, Stevens, Kathy \& Daniels, Peggy. (2009). Successful Single-Sex Classrooms. San Francisco: Jossey-Bass.

Neu, Terry W. \& Weinfeld, Rich. (2007). Helping Boys Succeed in School. Texas: Prufrock Press.

Norfleet-James, Abigail. (2007). Teaching the Male Brain. London: Corwin Press.

Richards, Jack C., \& Lockhart, Charles. (1999). Reflective Teaching in Second Language Classrooms. New York: Cambridge University Press.

Sax, Leonard. (2005). Why Gender Matters. New York: Doubleday.

\section{Personal interviews}

Hicks, Patrick. Personal communication. September 28, 2009.

Gómez, Luis. Personal communication. August 28, 2009. 